Journal of Anatolian Environmental and Animal Sciences

(Anadolu Çevre ve Hayvancıllk Bilimleri Dergisi)

DOI: https://doi.org/10.35229/jaes.702810

\title{
Human Health Risk Assessment of Heavy Metals Via Dietary Intake of Rainbow Trout from Samsun Fish Markets
}

\author{
Öztekin YARDIM* Levent BAT \\ University of Sinop, Fisheries Faculty, Department of Hydrobiology, 57000 Sinop, Turkey
}

How to cite: Yardım, Ö. \& Bat, L. (2020). Human Health Risk Assessment of Heavy Metals Via Dietary Intake of Rainbow Trout from Samsun Fish Markets. J. Anatolian Env. and Anim. Sciences, 5(2), 260-263.

Atıf yapmak için: Yardım, Ö. \& Bat, L. (2020). Samsun Balık Pazarlarından Gökkuşağı Alabalığı Tüketimi ile Ağır Metallerin İnsan Sağlığı Risk Değerlendirmesi. Anadolu Çev. ve Hay. Dergisi, 5(2), 260-263.

(iD): https://orcid.org/0000-0002-7753-5922 (iD): https://orcid.org/0000-0002-2289-6691

\section{*Corresponding author's:}

Öztekin YARDIM

University of Sinop, Fisheries Faculty, Department of Hydrobiology, 57000 Sinop, Turkey

凶: oyardim@sinop.edu.tr

Mobile telephone : +90 (533) 5635485

Telephone : $+90(368) 2876265$

Fax $\quad:+90(368) 2876268$

\begin{abstract}
Fish are an important part of the diet of the local people in the coasts of the Black Sea. The concentrations of three essential ( $\mathrm{Fe}, \mathrm{Zn}, \mathrm{Cu}$ ) and three non-essential ( $\mathrm{Pb}, \mathrm{Hg}, \mathrm{Cd}$ ) heavy metals were determined in Rainbow trout from Samsun fish market. In the present study, the maximum amounts of the toxic metals were $0.014 \mathrm{~Pb} \mathrm{mg} \mathrm{kg}^{-1}$ wet wt., $0.024 \mathrm{Hg} \mathrm{mg} \mathrm{kg}^{-1}$ wet wt. and $0.018 \mathrm{Cd} \mathrm{mg} \mathrm{kg}^{-1}$ wet wt. in the edible tissues of Rainbow trout. Maximum toxic heavy metal values are quite below the permitted values set by the Turkish Food Codex (TFC) and European Union legislation. Hazardous quotient (HQ) values showed that there was no apparent risk when each metal was analysed individually. Moreover, hazard index (HI) was also found to be less than 1. From the results the HQ of the heavy metals indicated that all Rainbow trout individuals were safe with no risk to consumers from Samsun.
\end{abstract}

Keywords: Hazard index, hazardous quotient, heavy metals, Rainbow trout, Samsun.

\section{Samsun Balık Pazarlarından Gökkuşağı Alabalığı Tüketimi ile Ağır Metallerin İnsan Sağlığı Risk Değerlendirmesi}

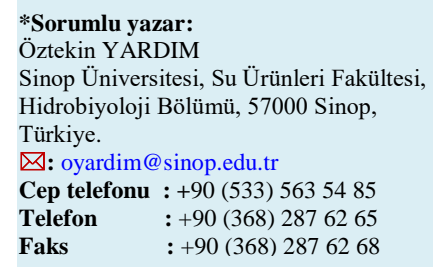

Öz: Balıklar Karadeniz kıyılarında halkın beslenmesinin önemli bir parçasıdır. Canlılar için üç esansiyel $(\mathrm{Fe}, \mathrm{Zn}, \mathrm{Cu})$ ve üç esansiyel olmayan $(\mathrm{Pb}, \mathrm{Hg}, \mathrm{Cd})$ ağır metal konsantrasyonları Samsun balık pazarından alınan Gökkuşağı alabalıklarında belirlenmiştir. Bu çalışmada Gökkuşağı alabalığının yenilebilir dokularında tespit edilen toksik metallerin maksimum miktarları, 0,014 $\mathrm{Pb} \mathrm{mg} \mathrm{kg}{ }^{-1}$ yaş ağırlık, $0,024 \mathrm{Hg} \mathrm{mg} \mathrm{kg}^{-1}$ yaş ağırlık ve $0,018 \mathrm{Cd} \mathrm{mg} \mathrm{kg}^{-1}$ yaş ağırlık olarak bulunmuştur. Maksimum toksik ağır metal değerleri, Türk Gıda Kodeksi (TGK) ve Avrupa Birliği mevzuatı tarafından izin verilen değerlerin oldukça altındadır. Tehlikeli katsayı (TK) değerleri, her metal için ayrı ayrı analiz edildiğinde belirgin bir riskin olmadığını göstermiştir. Ayrıca, tehlike indeksi (Ti்) de l'den az bulunmuştur. Sonuçlardan, ağır metallerin Tİ'si tüm Gökkuşağı alabalığı tüketiciler için hiçbir risk olmaksızın güvenli olduğunu göstermiştir.

$\underline{\text { Anahtar kelimeler: Ağır metaller, Gökkușağ }{ }_{1} \text { alabalığı, Samsun, tehlike indeksi, tehlikeli }}$ katsay1. 


\section{INTRODUCTION}

There is increasing attention to detect heavy metal contamination in fish today (Bat \& Arici, 2018). Essential metals are beneficial for humans, but non-essential heavy metals are extremely harmful. Intake of fish is one of the main pathways of heavy metal toxicity to people. Heavy metals are known the most marked forms of contamination in the marine ecosystem. This is since heavy metals are not simply biodegradable and as a consequence can be accumulated in human vital organs. This can cause serious illnesses and even deaths (Bat et al., 1999).

Fish is accepted necessary to a healthy diet because it has quality protein, high content of omega-3 polyunsaturated fatty acids, providing vitamins and a wide range of nutrients (De Lorgeril et al., 1994). Rainbow trout are very delicious and popular fish and are frequently consumed in Samsun, but information on the health risks of the heavy metals is rare. The hazard quotient (HQ), which is a ratio of determined amount of a contaminant to the reference dose level. If the ratio is less than 1 , there will not be any explicit risk. On the other hand, an exposed people will lifetime health risks if the amount is equal to or higher than the reference dose (EFSA, 2010; European Food Safety Authority, 2012; EFSA, 2012; EFSA, 2014; EFSA, 2015). Risk estimation method was applied in the present study. The main objective of this study is to estimate the health risks of heavy metals, such as Fe, Zn, $\mathrm{Cu}, \mathrm{Pb}, \mathrm{Cd}$ and $\mathrm{Hg}$ via consumption of Rainbow trout to the people in Samsun using the HQ estimates.

\section{MATERIAL AND METHOD}

The origin of fresh samples (Oncorhynchus mykiss Walbaum, 1792) was fish markets of Samsun Balık Hali (Fishing Store). Rainbow trout samples collected randomly from different fish markets in 2017. A total of 20 Rainbow trout individuals were purchased as fresh. To obtain three homogeneous samples of each individuals for metal analysis, a portion of muscle tissue was taken from the dorsal muscles according to the process described by Bernhard (1976). Analyses was replicated three times. Concentrations were calculated on a wet weight basis.

Metal analysis in fish was performed using mAOAC 999.10- ICP/MS (Inductively Coupled Plasma Mass Spectrometer) method by accredited Environment Industrial Analysis Laboratory Services Trade Company (TÜRKAK Test TS EN ISO IEC 17025 AB-0364-T). EN 15763 European Standard methods was applied. The sensitivity of the method was determined according to the detection limits established for the ICP/MS, which were < $0.001 \mu \mathrm{g} / \mathrm{L}$ for $\mathrm{Fe}, \mathrm{Pb}$ and $\mathrm{Cd},<0.01 \mathrm{Zn}$ and $\mathrm{Hg}$ and $<$ $0.0001 \mu \mathrm{g} / \mathrm{L}$ for $\mathrm{Cu}$.

\section{Health risk calculation}

Estimated Daily Intake (EDI): For the EDI the average metal content in each individual was calculated and multiplied by the respective consumption rate. EDI was determined by the following equation (1):

(1) $\mathrm{EDI}=\mathrm{C}_{\text {(Metal amounts) }} \times \mathrm{W}$ (fish intake) $/$ Body Weight (70 kg for adults)

Where,

$\mathrm{C}_{\text {(Metal amounts) }}=$ Heavy metal concentration in Rainbow trout $(\mathrm{mg} / \mathrm{kg}) ; \mathrm{W}_{\text {(fish intake) }}=$ Daily intake of fish (kg person ${ }^{-1}$ day $^{-1}$ wet wt.).

The average daily fish intake rate is $15 \mathrm{~g}$ in 2017 (TUIK, 2019).

Hazardous Quotient (HQ) and Hazard Index (HI): In this study a value of intake of these heavy metals in Rainbow trout was calculated to estimate the risk to human health via consumption. Hazardous Quotient (HQ) for people through the consumption of contaminated Rainbow trout was assessed by the ratio of EDI to the oral reference dose (Rf. D, mg/kg/day) for each metal. An estimate of risk to HQ through consumption of metal contaminated fish was calculated by the following equation (2):

(2) $\mathrm{HQ}=\mathrm{EDI} / \mathrm{Rf}$. D.

Oral reference doses (Rf. D.) $\mathrm{mg} \mathrm{kg}^{-1} \mathrm{day}^{-1}$ for Fe, $\mathrm{Zn}, \mathrm{Cu}, \mathrm{Pb}, \mathrm{Cd}$ and $\mathrm{Hg}$ are 0.7, 0.3, 0.04, 0.004, 0.001 and $0.0005 \mathrm{mg} / \mathrm{kg} /$ day, respectively (The Risk Assessment Information System, 2019).

The HI is the sum of the HQs for all heavy metals, which was calculated by the equation (3):

(3) $\mathrm{HI}=\sum \mathrm{HQ}_{\mathrm{s}}=\mathrm{HQ}_{(\mathrm{Fe})}+\mathrm{HQ}_{(\mathrm{Zn})}+\mathrm{HQ}_{(\mathrm{Cu})}+\mathrm{HQ}_{(\mathrm{Pb})}$ $+\mathrm{HQ}_{(\mathrm{Cd})}+\mathrm{HQ}_{(\mathrm{Hg})}$

If the $\mathrm{HI}$ value is less than 1 , the local consumers exposed are said to be safe, if $\mathrm{HI}$ is equal to or higher than 1 , it is considered unsafe for people's health, so potential health risk and related treatments and preventive measures should be taken.

Statistical analysis: Statistical significance of means was computed using one-way ANOVA and Duncan multiple range test were used to calculate the significant difference in the concentrations of studied metals, with a significance level of $\mathrm{P}<0.05$. Statistical analysis of data was performed by IBM SPSS 21 .

\section{RESULTS}

$\mathrm{Fe}, \mathrm{Zn}$ and $\mathrm{Cu}$ are essential heavy metals which may exert toxicity at high concentrations. Non-essential heavy metals such as $\mathrm{Pb}, \mathrm{Hg}$ and $\mathrm{Cd}$, have no biological functions and their intake can lead to adverse health effects (Bat, 2014; Bat, 2017). Results of the present study on heavy metals ( $\mathrm{Fe}, \mathrm{Zn}, \mathrm{Cu}, \mathrm{Pb}, \mathrm{Cd}$ and $\mathrm{Hg}$ ) in Rainbow trout 
from Samsun fish markets are given in Figure $1 . \mathrm{Pb}, \mathrm{Hg}$ and $\mathrm{Cd}$ levels were below the limit of quantitation values in some samples of Rainbow trout individuals. However, the mean values for each metal were given in Figure 1.
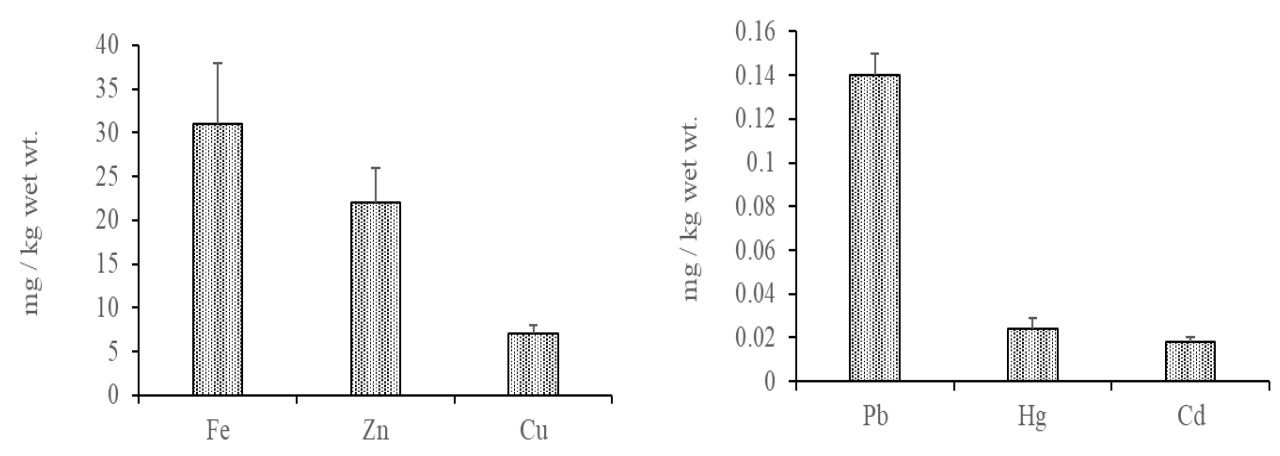

Figure 1. $\mathrm{Fe}, \mathrm{Zn}, \mathrm{Cu}, \mathrm{Pb}, \mathrm{Hg}$ and $\mathrm{Cd}$ levels in Rainbow trout from Samsun fish markets in 2017.

Currently, limit values permitted by international (EU) and national (Turkish Food Codex) organizations (European Commission, 2006; Turkish Food Codex, 2008) are not available for essential heavy metals (Bat et al., 2020). In the present study maximum non-essential heavy metal values determined in Rainbow trout are clearly below the permitted values set by the TFC and EU legislations. The maximum amounts set by the EC Regulation and TFC for $\mathrm{Pb}, \mathrm{Hg}$ and $\mathrm{Cd}$ in Rainbow trout are $0.3,0.50$ and $0.050 \mathrm{mg} / \mathrm{kg}^{-1}$ wet wt., respectively (Turkish Food Codex (TFC) No. 2008/26; Commission Regulation (EC) No. 1881/2006). The maximum amounts of the present study were $0.014 \mathrm{~Pb} \mathrm{mg} \mathrm{kg}^{-1}$ wet wt., 0.024 $\mathrm{Hg} \mathrm{mg} \mathrm{kg}{ }^{-1}$ wet wt. and $0.018 \mathrm{Cd} \mathrm{mg} \mathrm{kg}^{-1}$ wet wt. in the edible tissues of Rainbow trout.

The low metals levels obtained for Rainbow trout in this study are in good agreement with previous studies from Sinop fish markets (Bat et al., 2018), from the Karakaya Dam Reservoir on the Firat River in eastern
Anatolia (Varol et al., 2017) and from the Firtına and Güneysu Rivers (Dizman et al., 2017).

The estimated exposure to studied heavy metals due to the Rainbow trout consumption was calculated, considering the mean values of this study and an average Turkish consumer $(70 \mathrm{~kg})$ in the year 2017 as a reference; it must be considered that the consumption of fish in Turkey is $17 \mathrm{~g}$ per day. Estimated daily intakes of heavy metals through the consumption of fish in the present study was less than tolerable daily intake limit set by the USEPA, IRIS (2013). In the current study, the highest EDI was found as $\mathrm{Fe}$. This was followed by $\mathrm{Zn}, \mathrm{Cu}, \mathrm{Pb}, \mathrm{Hg}$ and $\mathrm{Cd}$. HQ was calculated for each metal. HQ values were calculated on the basis of the oral reference dose, there was no apparent risk when each metal was analysed individually. Its sum (HI) was also found to be less than 1, which means that consuming fish is not harmful to human health.

Table 1. People health risk parameters in Rainbow trout from Samsun fish markets.

\begin{tabular}{lccccc}
\hline \multirow{2}{*}{ Health Risks } & \multicolumn{4}{c}{ Heavy metals } \\
\cline { 2 - 6 } & $\mathrm{Fe}$ & $\mathrm{Zn}$ & $\mathrm{Cu}$ & $\mathrm{Pb}$ & $\mathrm{Cd}$ \\
\hline EDIs & $6.64 \times 10^{-3}$ & $4.71 \times 10^{-3}$ & $1.5 \times 10^{-3}$ & $3 \times 10^{-5}$ & $5.1 \times 10^{-6}$ \\
\hline HQs & $9.48 \times 10^{-3}$ & $1.57 \times 10^{-2}$ & $3.75 \times 10^{-2}$ & $7.5 \times 10^{-3}$ & $1.03 \times 10^{-2}$ \\
\hline HI & & \multicolumn{5}{c}{$8.43 \times 10^{-2}$} & & $3.86 \times 10^{-3}$ & \\
\hline
\end{tabular}

The finding of the present study regarding HQs and HI showed that the consumption of Rainbow trout from Samsun fish markets was free of health risks. Regular monitoring of heavy metal contamination in seafood is necessary in order to reduce the health risk. Rainbow trout is one of the most widely and most frequently consumed fish. Thus, popular fish, such as Rainbow trout, can be used for biomonitoring the marine contamination.

According to the results of the present study and Turkish and EU legislations, the contribution of $\mathrm{Fe}, \mathrm{Zn}, \mathrm{Cu}$,
$\mathrm{Pb}, \mathrm{Hg}$ and $\mathrm{Cd}$ through Rainbow trout to the Turkish diet does not hazard a risk to the consumer from Samsun.

\section{CONCLUSION}

Average concentrations of essential and toxic metals in Rainbow trout were negligible. These values were far below the limit levels set by the TFC and EU Regulations. As a conclusion the contribution studied heavy metals through Rainbow trout to the Turkish diet does not pose a risk to the consumer, according to national and international legislations. 


\section{ACKNOWLEDGEMENTS}

The authors wish to acknowledge the Department of Hydrobiology, Fisheries Faculty, University of Sinop for providing laboratory facilities during the study.

\section{CONFLICT OF INTEREST STATEMENT}

The authors declare that there are no conflicts of interest.

\section{REFERENCES}

Bat, L. (2014). Heavy metal pollution in the Black Sea. In: Düzgüneş E, Öztürk B, Zengin M. (Eds.). Turkish Fisheries in the Black Sea. Turkish Marine Research Foundation (TUDAV), Istanbul, Turkey, 40, 71-107.

Bat, L. (2017). The Contamination Status of Heavy Metals in Fish from the Black Sea, Turkey and Potential Risks to Human Health. In: Sezgin, M., Bat, L., Ürkmez, D., Arıcı, E., Öztürk, B. (Eds.) Black Sea Marine Environment: The Turkish Shelf. Turkish Marine Research Foundation (TUDAV), Istanbul, TURKEY, 46, 322-418.

Bat, L. \& Arici, E. (2018). Heavy metal levels in fish, molluscs, and crustacea from Turkish seas and potential risk of human health. In Food Quality: Balancing Health and Disease 159-196p. Elsevier Inc., Academic Press: UK.

Bat, L., Gündoğdu, A. \& Öztürk, M. (1999). Ağır metaller. SDÜ Ĕgridir Su Ürünleri Fakültesi Dergisi, 6, 166-175.

Bat, L., Oztekin, A. \& Yardim, O. (2018). Metal levels in large sea trout from Sinop fish market. Fresenius Environmental Bulletin, 27(12), 85058508.

Bat, L., Öztekin, A., Arici, E. \& Şahin F. (2020). Health risk assessment: heavy metals in fish from the southern Black Sea. Foods and Raw Materials, $8(1), 115-124$.

Bernhard, M. (1976). Manual of methods in aquatic environment research. Part 3-Sampling and analyses of biological material (guidelines for the FAO (GFCM)/UNEP Joint Coordinated Project on Pollution in the Mediterranean). Documents Techniques FAO sur les Pèches (FAO).

De Lorgeril, M., Renaud, S., Salen, P., Monjaud, I., Mamelle, N., Martin, J.L., Monjaud, I., Guidollet, J., Touboul, P. \& Delaye, J. (1994). Mediterranean alpha-linolenic acid-rich diet in secondary prevention of coronary heart disease. The Lancet, 343(8911), 1454-1459.

Dizman, S., Görür, F.K. \& Keser, R. (2017). Assessment of human health risk from heavy metals levels in water and tissues of two trout species (Oncorhynchus mykiss and Salmo coruhensis) from the Firtına and Güneysu Rivers in Turkey. Toxin Reviews, 36(4), 306-312.

EFSA Panel on Contaminants in the Food Chain (CONTAM). (2010). Scientific Opinion on lead in food. EFSA Journal, 8(4), 1570.

EFSA Panel on Contaminants in the Food Chain (CONTAM). (2012). Scientific Opinion on the risk for public health related to the presence of mercury and methylmercury in food. EFSA Journal, 10(12), 2985.

EFSA Dietetic Products, Nutrition, and Allergies (NDA). (2014). Scientific Opinion on health benefits of seafood (fish and shellfish) consumption in relation to health risks associated with exposure to methylmercury. EFSA journal, 12(7), 3761.

EFSA Scientific Committee. (2015). Statement on the benefits of fish/seafood consumption compared to the risks of methylmercury in fish/seafood. EFSA journal, 13(1), 3982.

European Commission. (2006). Commission Regulation (EC) No 1881/2006 of 19 December 2006 setting maximum levels for certain contaminants in foodstuffs. Off J Eur Union, 364(365-324).

European Food Safety Authority. (2012). Cadmium dietary exposure in the European population. Efsa Journal, 10(1), 2551.

The Risk Assessment Information System (RAIS). (2019). University of Tennessee, Available from: https://rais.ornl.gov/index.html.

TUIK, Turkish Fishery Statistics (2019). Available from: http://www.tuik.gov.tr/.

Turkish Food Codex (2008). Turkish food codex communiqué on determining the maximum levels of certain contaminants in foodstuffs. The Official Gazette, 17(2008), 26879.

U.S. Environmental Protection Agency, (IRIS) (2013). Washington, DC. Integrated Risk Information System, Available at: http://www.epa.gov/iris/.

Varol, M., Kaya, G.K. \& Alp, A. (2017). Heavy metal and arsenic concentrations in rainbow trout (Oncorhynchus mykiss) farmed in a dam reservoir on the Firat (Euphrates) River: Risk-based consumption advisories. Science of the Total Environment, 599, 1288-1296. 